\title{
Effect of Elevated Temperature Storage on the Digestible Reactive Lysine Content of Unhydrolyzed- and Hydrolyzed-Lactose Milk-Based Products
}

\author{
S. M. Rutherfurd ${ }^{1}$ and P. J. Moughan \\ Riddet Centre, Massey University, Palmerston North, New Zealand 4474
}

\begin{abstract}
The study aimed to evaluate the effects of storage at elevated temperatures on reactive Lys content and true ileal reactive Lys digestibility in a skim milk powder and a hydrolyzed-lactose skim milk powder. A validated bioassay based on guanidination of food and digesta samples was applied. Semisynthetic diets containing the milk powders as the sole sources of protein were formulated and fed to growing rats. Chromic oxide was included in each diet as an indigestible marker. Digesta were collected posteuthanasia and analyzed along with the diets for reactive Lys (homoarginine), and true ileal reactive Lys digestibility was calculated after correction for endogenous Lys loss. For the skim milk powder, there was no decrease in reactive Lys digestibility (Lys availability) when the powder was stored at 30 and $35^{\circ} \mathrm{C}$ for $18 \mathrm{mo}$. In contrast, when stored at $40^{\circ} \mathrm{C}$ for $12 \mathrm{mo}$, a small but statistically significant (6\%) decrease was observed. For the hydrolyzed-lactose product, a $22 \%$ decrease in Lys availability was observed after storage at $35^{\circ} \mathrm{C}$ for $18 \mathrm{mo}$, and a $17 \%$ decrease was observed when stored at $40^{\circ} \mathrm{C}$ for only $6 \mathrm{mo}$. Digestible reactive (available) Lys content decreased by more than $20 \%$ for the skim milk powder stored at 30 and $35^{\circ} \mathrm{C}$ for $18 \mathrm{mo}$ and $40 \%$ when stored at $40^{\circ} \mathrm{C}$ for $12 \mathrm{mo}$. Furthermore, available Lys decreased in the hydrolyzed-lactose skim milk powder by $41 \%$ when stored at $30^{\circ} \mathrm{C}$ for only $18 \mathrm{mo}$ and 34 and $65 \%$ when stored at 35 and $40^{\circ} \mathrm{C}$, respectively, for 6 mo. Elevated temperatures and prolonged storage periods negatively influenced the available Lys contents of both milk powders. The decrease in available Lys content and Lys availability was greater for the hydrolyzed-lactose skim milk powder compared with the normal skim milk powder, after storage at elevated temperatures.
\end{abstract}

Key words: lysine, milk, availability, storage

Received August 13, 2007.

Accepted October 30, 2007.

${ }^{1}$ Corresponding author: S.M.Rutherfurd@massey.ac.nz

\section{INTRODUCTION}

Lysine is often the first-limiting indispensable AA in diets for humans, underlining the nutritional importance of milk proteins, which are significant dietary sources of Lys. In milk products that undergo heat processing or during storage, however, the $\varepsilon$-amino group of Lys can react with compounds in milk, particularly milk sugars, to produce nutritionally unavailable derivatives (Hurrell and Carpenter, 1981; Moughan, 2003). Some of these derivatives are acid labile and revert back to Lys during the acid hydrolysis step of conventional AA analysis, leading to inaccuracy in the determination of the Lys and digestible Lys contents of processed milk products (Rutherfurd and Moughan, 2005). There are a number of methods that can be used to accurately determine the chemically reactive Lys content of processed protein sources, including the fluoro-2,4-dinitrobenzene (FNBS), 2,4,6-trinitrobenzenesulfonic acid (TNBS), and guanidination methods (Hurrell and Carpenter, 1974). However, these techniques do not take into account the incomplete absorption from the small intestine that can occur with a damaged protein. A method has been developed (Moughan and Rutherfurd, 1996) that accurately determines digestible reactive (available) Lys in processed foods (Rutherfurd et al., 1997). The assay utilizes the guanidination reaction, specific to the $\varepsilon$-amino group of Lys (Klee and Richards, 1957; Kassell and Chow, 1966; Moughan and Rutherfurd, 1996; Catrein et al., 2005; Yamaguchi et al., 2005; Zhang et al., 2006), to determine the amounts of reactive Lys in both diet and digesta for an animal fed that test diet. Reactive Lys digestibility is then calculated as the difference between dietary reactive Lys intake and ileal reactive Lys output. The assay has been applied to selected milk-based products (Rutherfurd and Moughan, 2005 ) to a variably heated skim milk powder (Rutherfurd and Moughan, 1997) and to a range of cereal breakfast foods (Rutherfurd et al., 2006). The aim of the present study was to apply the assay to determine the effect of long-term storage at elevated temperatures $\left(30\right.$ to $\left.40^{\circ} \mathrm{C}\right)$ on digestible reactive Lys content in an unhydrolyzed and hydrolyzed-lactose skim milk powder. The study 
Table 1. Conditions used to test the effect of storage duration and air temperature on digestible reactive Lys contents in a skim milk powder and a hydrolyzed-lactose skim milk powder

\begin{tabular}{|c|c|c|c|c|c|c|}
\hline \multirow{3}{*}{$\begin{array}{l}\text { Storage } \\
\text { time (mo) }\end{array}$} & \multicolumn{6}{|c|}{ Storage temperature $\left({ }^{\circ} \mathrm{C}\right)$} \\
\hline & \multicolumn{3}{|c|}{ Skim milk powder } & \multicolumn{3}{|c|}{ Hydrolyzed-lactose skim milk powder } \\
\hline & 30 & 35 & 40 & 30 & 35 & 40 \\
\hline 0 & $\mathrm{X}^{1}$ & $\mathrm{X}$ & $\mathrm{X}$ & $\mathrm{X}$ & $\mathrm{X}$ & $X$ \\
\hline 1.5 & & & $\mathrm{X}$ & & & $\mathrm{X}$ \\
\hline 3 & $\mathrm{X}$ & $\mathrm{X}$ & $\mathrm{X}$ & $\mathrm{X}$ & $\mathrm{X}$ & $\mathrm{X}$ \\
\hline 4.5 & & & & & & $\mathrm{X}$ \\
\hline 6 & $X$ & $\mathrm{X}$ & $\mathrm{X}$ & $X$ & $\mathrm{X}$ & $\mathrm{X}$ \\
\hline 9 & $X$ & $\mathrm{X}$ & $X$ & X & $\mathrm{X}$ & \\
\hline 12 & $\mathrm{X}$ & $\mathrm{X}$ & $\mathrm{X}$ & $\mathrm{X}$ & $\mathrm{X}$ & \\
\hline 15 & & & & & $X$ & \\
\hline 18 & $X$ & $X$ & & $X$ & $\mathrm{X}$ & \\
\hline
\end{tabular}

${ }^{1} \mathrm{An} \mathrm{X}$ indicates that a sample of either skim milk powder or hydrolyzed-lactose skim milk powder underwent storage at the corresponding time and temperature.

sought to determine the degree of protein damage and indicate shelf life for products stored under temperatures encountered in warmer world climates.

\section{MATERIALS AND METHODS}

\section{Materials}

$O$-Methylisourea was obtained from Sigma Chemicals (St. Louis, MO) and barium hydroxide octahydrate from BDH Laboratory Supplies (Poole, UK). Two milk-based protein products were obtained locally; these included a commercial skim milk powder and a commercial hydrolyzed-lactose skim milk powder. The protein content of the milk powders was determined on a Leco analyzer using the Dumas method (IDF, 1993), and CP was calculated as the total $\mathrm{N}$ content multiplied by 6.38 . The skim milk powder and the hydrolyzed-lactose skim milk powder contained 37.5 and $38.2 \%$ protein, respectively. Laboratory rats were obtained from the Small Animal Production Unit, Massey University, Palmerston North, New Zealand.

\section{Storage Conditions}

The skim milk powder and the corresponding hydrolyzed-lactose skim milk powder were stored in a temperature-controlled room at 30,35 , and $40^{\circ} \mathrm{C}$ in $500-\mathrm{g}$ lots in vacuum-sealed sample bags for up to $18 \mathrm{mo}$. The storage regimen is shown in Table 1.

\section{Digestibility Study}

One hundred and sixty male Sprague-Dawley rats of approximately $150 \mathrm{~g}$ of BW were housed individually in stainless steel wire-bottomed cages in a room maintained at $22 \pm 2^{\circ} \mathrm{C}$, with a 12 -h light-dark cycle. Thirtytwo semisynthetic wheat starch-based test diets were formulated to each contain $100 \mathrm{~g} / \mathrm{kg}$ of $\mathrm{CP}$. The ingredient compositions of the experimental diets are shown in Table 2. Chromic oxide was included $(0.5 \%)$ in each diet as an indigestible marker. All diets met the nutritional requirements of the growing rat with the exception of protein (NRC, 1995). The animals were randomly allocated to the dietary treatments such that there were 5 animals per treatment, and they were fed their respective diets for a 14-d experimental period. On each day, each rat received its diet as 9 meals given hourly $(0830$ to $1630 \mathrm{~h}$ ); each meal time consisted of a 10 -min period in which the rats had unrestricted access to their diet. Water was available at all times. On the final day of the study, from 5.5 to $7 \mathrm{~h}$ after the start of feeding, the rats were asphyxiated using $\mathrm{CO}_{2}$ gas and then decapitated. The $20 \mathrm{~cm}$ of ileum immediately anterior to the ileo-

Table 2. Ingredient compositions ${ }^{1}$ ( $\mathrm{g} / \mathrm{kg}$ of air dry weight) of the experimental diets

\begin{tabular}{lcc}
\hline Item & $\begin{array}{c}\text { Skim milk } \\
\text { powder }\end{array}$ & $\begin{array}{c}\text { Hydrolyzed-lactose } \\
\text { skim milk powder }\end{array}$ \\
\hline Wheat starch & 433 & 428 \\
Soybean oil & 50 & 50 \\
Cellulose & 50 & 50 \\
Sucrose & 100 & 100 \\
Vitamin premix & 50 & 50 \\
Mineral premix & 4 & 50 \\
Skim milk powder & 50 & - \\
Hydrolyzed-lactose milk powder & 262 & 267 \\
Chromic oxide & - & 5
\end{tabular}

\footnotetext{
${ }^{1}$ All diets were formulated to contain equal CP contents.

${ }^{2}$ All the skim milk powder-based diets for samples stored at the varying times and temperatures were prepared using this formulation.

${ }^{3}$ All the hydrolyzed-lactose skim milk powder-based diets for samples stored at the varying times and temperatures were prepared using this formulation.

${ }^{4}$ Vitamin-mineral mix was formulated to meet the requirements of the growing rat for vitamins and minerals in the final diets (NRC, 1995).
} 
cecal junction was dissected out, carefully washed with distilled deionized water, and dried on absorbent paper. The digesta were gently flushed from the ileum section with distilled deionized water and freeze-dried ready for chemical analysis.

Ethics approval for the animal trial was obtained from the Animal Ethics Committee, Massey University, Palmerston North, New Zealand.

\section{Chemical Analysis}

Reactive Lys contents were determined in duplicate 5-mg milk powder and digesta samples and quadruplicate 5-mg diet samples after incubation for 1,7 , and 7 $\mathrm{d}$, respectively, in $0.6 \mathrm{MO}$-methylisourea, $\mathrm{pH} 10.6 \mathrm{pH}$ 11.0 for the digesta samples), at $21^{\circ} \mathrm{C}$ in a shaking water bath, with the reagent:Lys ratio being greater than 1,000 , according to the procedure of Moughan and Rutherfurd (1996). The 0.6 MO-methylisourea solution was prepared as described by Moughan and Rutherfurd (1996). After incubation, the samples were dehydrated using a Speedvac concentrator (Savant Instruments Inc, Farmingdale, NY) and analyzed for homoarginine using a Waters ion-exchange HPLC system, utilizing postcolumn ninhydrin derivatization and detection using absorbance at $570 \mathrm{~nm}$, after hydrolysis in $6 M$ glass-distilled $\mathrm{HCl}$ containing $0.1 \%$ phenol for $24 \mathrm{~h}$ at $110 \pm 2^{\circ} \mathrm{C}$ in evacuated sealed tubes. The weight of reactive Lys was calculated from the determined molar quantity of homoarginine and the molecular weight for free Lys.

The Cr contents of the diet and ileal digesta samples were determined in duplicate on a GBC 902 AA absorption-emission spectrophotometer (GBC Scientific NZ Ltd., Auckland, New Zealand) following the method of Costigan and Ellis (1987).

\section{Data Analysis}

Ileal reactive Lys flows at the terminal ileum were calculated using the following equation (units are $\mu \mathrm{g} / \mathrm{g}$ of DMI): ileal reactive Lys flow $=$ ileal reactive Lys $\times$ diet Cr/ileal Cr.

True ileal reactive Lys digestibility was calculated using the following equation (units are $\mu \mathrm{g} / \mathrm{g}$ of DMI): True ileal reactive Lys digestibility $(\%)=$ [dietary reactive Lys intake - (ileal reactive Lys flow - endogenous Lys flow)]/ dietary reactive Lys intake $\times 100$. The Lys flow was based on the endogenous AA flows for the growing rat reported by Rutherfurd and Moughan (1998).

The reactive Lys digestibility and digestible reactive Lys data were analyzed, using an analysis of covariance. The covariate was fitted as an exponential form. Temperature and milk powder type were fixed factors, and time was the covariate. Fixed factor effects were incorporated into the model by means of the dummy variable technique (Zar, 1984). SigmaPlot (Jandel Scientific, San Raphael, CA) software was used for model fitting.

\section{RESULTS}

\section{The Effect of Storage on the Reactive Lys Content of a Skim Milk Powder and a Hydrolyzed-Lactose Skim Milk Powder}

The 2 milk powders (skim milk powder and hydrolyzed-lactose skim milk powder) were stored at 30, 35 , and $40^{\circ} \mathrm{C}$ from 0 to $18 \mathrm{mo}$. The reactive Lys content of the milk powders was determined periodically throughout this storage period, and the results are shown in Table 3. For the skim milk powder stored at 30 and $35^{\circ} \mathrm{C}$, the reactive Lys content decreased linearly $\left(\mathrm{R}^{2}=0.93\right.$ and 0.94 for the skim milk powder stored at 30 and $35^{\circ} \mathrm{C}$, respectively) from $33 \mathrm{~g} / \mathrm{kg}$ initially to approximately $26 \mathrm{~g} / \mathrm{kg}$ after $18 \mathrm{mo}$ of storage. The reactive Lys content of the skim milk powder stored at $40^{\circ} \mathrm{C}$ decreased linearly $\left(R^{2}=0.94\right)$ from 33 to $21 \mathrm{~g} / \mathrm{kg}$ after 12 mo of storage.

For the hydrolyzed-lactose skim milk powder stored at $30^{\circ} \mathrm{C}$, the reactive Lys content decreased linearly $\left(\mathrm{R}^{2}=\right.$ 0.99) from $28 \mathrm{~g} / \mathrm{kg}$ initially to $18 \mathrm{~g} / \mathrm{kg}$ after $18 \mathrm{mo}$ of storage, whereas over the same storage period, the reactive Lys content in the hydrolyzed-lactose milk powder stored at $35^{\circ} \mathrm{C}$ decreased linearly $\left(\mathrm{R}^{2}=0.90\right)$ from 28 to $13 \mathrm{~g} / \mathrm{kg}$. When this hydrolyzed-lactose milk powder was stored at $40^{\circ} \mathrm{C}$, the reactive Lys content decreased linearly $\left(R^{2}=0.91\right)$ from 28 to $12 \mathrm{~g} / \mathrm{kg}$ after only $6 \mathrm{mo}$ of storage.

\section{True Ileal Reactive Lys Digestibility of a Skim Milk Powder and a Hydrolyzed-Lactose Skim Milk Powder Before and After Storage}

The determined mean true ileal reactive Lys digestibilities for the 2 products determined before and after storage are shown in Table 4. The reactive Lys digestibility of both the skim milk powder and hydrolyzed-lactose skim milk powder before storage was $100 \%$. There was a statistically significant effect of time and temperature on the true ileal reactive Lys digestibility $(P<0.001$ and 0.05 , respectively), in which digestibility decreased with increasing storage temperature and storage time. There was a significant interaction $(P<0.001)$ between milk powder type and time $(P<0.001)$ and temperature $(P<$ 0.001 ) in which digestibility decreased to a greater degree in the hydrolyzed-lactose skim milk powder than the normal skim milk powder as storage temperature and time increased. There was also a significant interaction $(P<0.001)$ between time and temperature. 
Table 3. Mean $( \pm \mathrm{SE})$ reactive Lys content ${ }^{1}$ ( $\mathrm{g} / \mathrm{kg}$ of air-dry weight) for a skim milk powder and a hydrolyzedlactose skim milk powder stored at 30,35 , and $40^{\circ} \mathrm{C}$ for varying time periods

\begin{tabular}{|c|c|c|c|c|c|c|}
\hline \multirow{3}{*}{$\begin{array}{l}\text { Storage } \\
\text { period (mo) }\end{array}$} & \multicolumn{6}{|c|}{ Storage temperature $\left({ }^{\circ} \mathrm{C}\right)$} \\
\hline & \multicolumn{3}{|c|}{ Skim milk powder } & \multicolumn{3}{|c|}{ Hydrolyzed-lactose skim milk powder } \\
\hline & 30 & 35 & 40 & 30 & 35 & 40 \\
\hline 0 & $33.0(0.06)$ & $33.0(0.06)$ & $33.0(0.06)$ & 28.0 & 28.0 & $28.0(1.8)$ \\
\hline 1.5 & & & $28.3(1.18)$ & & & $19.6(0.30)$ \\
\hline 3 & $31.3(1.38)$ & $31.3(2.14)$ & $28.1(0.70)$ & $27.0(0.10)$ & $22.7(0.82)$ & $16.8(1.05)$ \\
\hline 4.5 & & & & & & $13.3(1.06)$ \\
\hline 6 & $29.8(0.01)$ & $30.1(0.13)$ & $26.1(0.07)$ & $24.0(0.04)$ & $18.9(0.65)$ & $11.7(0.40)$ \\
\hline 9 & $29.7(0.19)$ & $28.8(0.14)$ & $22.1(5.03)$ & $22.4(0.10)$ & $18.2(0.08)$ & \\
\hline 12 & 26.4 (1.99) & $25.7(0.21)$ & $21.0(0.10)$ & $21.2(0.43)$ & $17.0(0.34)$ & \\
\hline 15 & & & & & $15.9(0.10)$ & \\
\hline 18 & $26.1(1.47)$ & $25.6(0.15)$ & & $17.9(0.64)$ & $12.6(0.00)$ & \\
\hline
\end{tabular}

${ }^{1}$ Mean values based on duplicate determinations.

\section{True Ileal Digestible Reactive (Available) Lys Content of a Skim Milk Powder and a Hydrolyzed-Lactose Skim Milk Powder Before and After Storage}

True ileal digestible reactive Lys contents for the skim milk powder and the hydrolyzed-lactose skim milk powder stored at elevated temperatures for up to 18 mo were determined (Table 5). There was a 20 and $23 \%(P<$ 0.001 ) decrease in digestible reactive Lys content for the skim milk powder stored for $18 \mathrm{mo}$ at 30 and $35^{\circ} \mathrm{C}$, respectively, whereas for the skim milk powder stored at $40^{\circ} \mathrm{C}$ for $12 \mathrm{mo}$, there was a $40 \%$ decrease $(P<0.001)$ in digestible reactive Lys content. For the hydrolyzedlactose skim milk powder stored for $18 \mathrm{mo}$ at 30 and $35^{\circ} \mathrm{C}$, there was a 41 and $65 \%(P<0.001)$ reduction in the digestible reactive Lys content, respectively. After only $6 \mathrm{mo}$ of storage at $40^{\circ} \mathrm{C}$, the digestible reactive Lys content of the hydrolyzed-lactose skim milk powder was also decreased by $65 \%$. The hydrolyzed-lactose skim milk powder suffered greater digestible reactive Lys loss with increasing storage time and temperature compared with the normal skim milk powder.

\section{DISCUSSION}

Lysine is a nutritionally important AA, and because of this, the accurate assessment of it's content and availability in foods is important. Lysine can be chemically modified during the processing or storage of foods to form nutritionally unavailable derivatives (e.g., Maillard products). Because some of these products can interfere with the chemical analysis of Lys, traditional methods for determining available Lys may not always be accurate. Recently, a new assay methodology for accurately determining ileal digestible reactive Lys (available Lys) has been developed (Moughan and Rutherfurd, 1996). This assay was used here to determine the available Lys content of a skim milk powder and a hydrolyzed-lactose skim milk powder after long-term storage at elevated temperatures.

\section{The Effect of Storage on the Reactive Lys Content of a Skim Milk Powder and a Hydrolyzed-Lactose Skim Milk Powder}

For the skim milk powder, the reactive Lys content decreased by approximately $22 \%$ when stored at 30 and

Table 4. Mean $(n=5)$ true ileal reactive Lys digestibility ${ }^{1}(\%)$ for a skim milk powder and a hydrolyzedlactose skim milk powder stored at 30,35 and $40^{\circ} \mathrm{C}$ for varying time periods

\begin{tabular}{|c|c|c|c|c|c|c|}
\hline \multirow{3}{*}{$\begin{array}{l}\text { Storage } \\
\text { period (mo) }\end{array}$} & \multicolumn{6}{|c|}{ Storage temperature $\left({ }^{\circ} \mathrm{C}\right)$} \\
\hline & \multicolumn{3}{|c|}{ Skim milk powder } & \multicolumn{3}{|c|}{ Hydrolyzed-lactose skim milk powder } \\
\hline & 30 & 35 & 40 & 30 & 35 & 40 \\
\hline 0 & 100 & 100 & 100 & 100 & 100 & 100 \\
\hline 1.5 & & & 99 & & & 94 \\
\hline 3 & 100 & 100 & 99 & 98 & 98 & 93 \\
\hline 4.5 & & & & & & 96 \\
\hline 6 & 100 & 100 & 99 & 99 & 98 & 83 \\
\hline 9 & 101 & 100 & 98 & 98 & 95 & \\
\hline 12 & 101 & 100 & 94 & 94 & 85 & \\
\hline 15 & & & & & 85 & \\
\hline 18 & 101 & 98 & & 94 & 78 & \\
\hline
\end{tabular}

\footnotetext{
${ }^{1}$ Reactive Lys digestibility was determined using a true ileal AA digestibility assay (rat). The guanidination reaction was used to quantitate reactive Lys in the diets and digesta.
} 
Table 5. Mean $\left( \pm \mathrm{SE}, \mathrm{n}=5\right.$ ) digestible reactive Lys contents ${ }^{1}$ ( $\mathrm{g} / \mathrm{kg}$ of air-dry weight) for a skim milk powder and a hydrolyzed-lactose skim milk powder stored at 30,35 and $40^{\circ} \mathrm{C}$ for varying time periods

\begin{tabular}{|c|c|c|c|c|c|c|}
\hline \multirow[b]{3}{*}{ Storage period (mo) } & \multicolumn{6}{|c|}{ Storage temperature $\left({ }^{\circ} \mathrm{C}\right)$} \\
\hline & \multicolumn{3}{|c|}{ Skim milk powder } & \multicolumn{3}{|c|}{ Hydrolyzed-lactose skim milk powder } \\
\hline & 30 & 35 & 40 & 30 & 35 & 40 \\
\hline 0 & $32.9(0.05)$ & $32.9(0.05)$ & $32.9(0.05)$ & $28.1(0.03)$ & $28.1(0.03)$ & $28.1(0.03)$ \\
\hline 1.5 & & & $28.0(0.08)$ & & & $18.4(0.13)$ \\
\hline 3 & $31.2(0.06)$ & $31.3(0.07)$ & $27.9(0.12)$ & $26.6(0.11)$ & $22.3(0.10)$ & $15.5(0.12)$ \\
\hline 4.5 & & & & & & $12.7(0.23)$ \\
\hline 6 & $29.8(0.12)$ & $30.3(0.07)$ & $25.9(0.39)$ & $23.9(0.27)$ & $18.5(0.21)$ & $9.7(0.58)$ \\
\hline 9 & $29.9(0.01)$ & $28.9(0.17)$ & $21.5(0.12)$ & $22.0(0.32)$ & $17.3(0.23)$ & \\
\hline 12 & $26.5(0.10)$ & $25.7(0.21)$ & $19.8(0.45)$ & $19.8(0.19)$ & $14.5(0.37)$ & \\
\hline 15 & & & & & $13.5(0.36)$ & \\
\hline 18 & $26.3(0.15)$ & $25.2(0.26)$ & & $16.7(0.23)$ & $9.9(0.35)$ & \\
\hline
\end{tabular}

${ }^{1}$ Digestible reactive Lys was calculated from true ileal reactive Lys digestibility (rat, guanidination analysis), and the reactive lysine content of the respective milk powder, which was also determined using guanidination.

$35^{\circ} \mathrm{C}$ for $18 \mathrm{mo}$, whereas during storage at $40^{\circ} \mathrm{C}$, the reactive Lys content decreased by $36 \%$ in only 12 mo. For the hydrolyzed-lactose skim milk powder, the reduction in reactive Lys content during storage at elevated temperatures was greater, with decreases of $36 \%$ after 18 mo of storage at $30^{\circ} \mathrm{C}, 55 \%$ after $18 \mathrm{mo}$ of storage at $35^{\circ} \mathrm{C}$, and $58 \%$ after $6 \mathrm{mo}$ of storage at $40^{\circ} \mathrm{C}$. In all cases, there was a considerable reduction in reactive Lys content after storage, suggesting extensive Lys damage had occurred to both milk powders after storage at elevated temperatures. Furthermore, and as expected, the reduction in Lys was greater in the milk powders stored at the higher temperatures. It is also interesting that the loss of Lys over time was very nearly linear for both products over all the temperatures tested.

It is of note that the Lys content decreased to a much greater extent and more rapidly in the hydrolyzed-lactose skim milk powder than in the normal skim milk powder. The reducing sugar content of the hydrolyzedlactose skim milk powder is twice that of the skim milk powder, because lactose (a reducing sugar) is hydrolyzed to glucose and galactose, which are in turn both reducing sugars. It is likely that the higher concentration of reducing sugars in the hydrolyzed-lactose product compared with it's unhydrolyzed counterpart explains the difference in Lys damage observed for the 2 milk powders.

\section{True Ileal Reactive Lys Digestibility of a Skim Milk Powder and a Hydrolyzed-Lactose Skim Milk Powder Before and After Storage}

The reactive Lys in the fresh skim milk powder was completely digested. Rutherfurd and Moughan (1997) also found the reactive Lys in skim milk powder to be highly digestible (100\%). For the skim milk powder stored at 30 and $35^{\circ} \mathrm{C}$, there was no reduction in reactive Lys digestibility over the 18-mo storage period. When stored at $40^{\circ} \mathrm{C}$, the reactive Lys digestibility did decrease after 12 mo of storage, but the decrease was not large (6\%). In contrast, a similar small decrease (6\%) in reactive Lys digestibility was observed for the hydrolyzedlactose skim milk powder when stored for 12 mo at only $30^{\circ} \mathrm{C}$. When stored at $35^{\circ} \mathrm{C}$, a similar (5\%) decrease was observed after only $9 \mathrm{mo}$, and after $18 \mathrm{mo}$ of storage, reactive Lys digestibility had decreased by $22 \%$. When stored at $40^{\circ} \mathrm{C}$, digestibility had dropped markedly (a $17 \%$ decrease) after only 6 mo.

Clearly, when skim milk powder underwent prolonged storage at elevated temperatures, Lys availability decreased, but this reduction was not large. In contrast, for a skim milk powder that had undergone lactose hydrolysis before storage, the decrease in Lys availability was large. The lactose hydrolysis process clearly had a major effect on the digestibility of reactive Lys when the products were stored for long periods of time at elevated temperatures, most likely an effect of greater Lys damage due to the higher concentration of reducing sugars in the hydrolyzed products. The decrease in reactive Lys digestibility may be brought about by a reduction in the effectiveness of trypsin in hydrolyzing the peptide bonds in proximity to the modified Lys residues. This would then further hinder digestion by other intestinal proteases such as chymotrypsin, resulting in the presence of indigestible limit peptides (Moughan et al., 1996). These limit peptides may contain any of the AA present in proteins and will therefore result in a reduction in the digestibility of all AA, not just Lys (Moughan and Rutherfurd, 1996).

\section{True Ileal Digestible Reactive (Available) Lys Content of a Skim Milk Powder and a Hydrolyzed-Lactose Skim Milk Powder Before and After Storage}

For the skim milk powder stored at 30 and $35^{\circ} \mathrm{C}$, the reduction in the true ileal digestible reactive Lys content 
after storage for 18 mo was large and was similar to the reduction observed for the gross reactive Lys content of the skim milk powder, because digestibility was essentially complete for these samples. When the skim milk powder was stored at $40^{\circ} \mathrm{C}$, the reduction in digestible reactive Lys was almost double that observed after storage at the lower temperatures after only two-thirds the storage time. For the hydrolyzed-lactose skim milk powder, the reduction in digestible reactive Lys content was very large even at the lower storage temperatures (30 and $35^{\circ} \mathrm{C}$ ), whereas for the samples stored at $40^{\circ} \mathrm{C}$, well over half of the digestible reactive Lys was destroyed after only 6 mo of storage.

Clearly, temperature plays a significant role in the stability of Lys in milk powders. Digestible reactive Lys content was $34 \%$ higher when the powders were stored at $30^{\circ} \mathrm{C}$ compared with storage at $40^{\circ} \mathrm{C}$ for the same length of time (12 mo). For the hydrolyzed-lactose product, this difference was even more dramatic with digestible reactive Lys content, being as much as 146\% higher in the product stored for $6 \mathrm{mo}$ at $30^{\circ} \mathrm{C}$ compared with the same time at $40^{\circ} \mathrm{C}$. Other studies have shown similar effects; van Barneveld et al. (1994) found a 73\% decrease in the available Lys content of field peas heated from 110 to $165^{\circ} \mathrm{C}$ when determined using an animal growth assay.

Overall, skim milk powder is a highly digestible, highquality protein source. However, there was a sizable loss of reactive Lys and digestible reactive Lys in the skim milk powder when stored at elevated temperatures for prolonged periods. Again, the effect was much more dramatic for the hydrolyzed-lactose product. The study demonstrates that at elevated temperatures, such as those experienced in warmer world climates, considerable Lys damage can occur in relatively short periods of time $(6$ mo) and that these may be high enough to warrant concern from a nutritional viewpoint. The study also demonstrates the utility of the BIOLYSINE assay (Moughan and Rutherfurd, 1996) in predicting the effects of storage on protein quality and evaluating product shelf life.

\section{ACKNOWLEDGMENTS}

We acknowledge the New Zealand Dairy Board for funding this study.

\section{REFERENCES}

Catrein, I., R. Herrmann, A. Bosserhoff, and T. Ruppert. 2005. Experimental proof for a signal peptidase 1 like activity in Mycoplasma pneumoniae, but absence of a gene encoding a conserved bacterial type 1 SPase. FEBS J. 272:2892-2900.

Costigan, P., and K. J. Ellis. 1987. Analysis of faecal chromium derived from controlled release marker devices. N. Z. J. Tech. 3:89-92.

Hurrell, R. F., and K. J. Carpenter. 1974. Mechanisms of heat damage in proteins. 4 . The reactive lysine content of heat-damaged material as measured in different ways. Br. J. Nutr. 32:589-604.

Hurrell, R. F., and K. J. Carpenter. 1981. The estimation of available lysine in foodstuffs after Maillard reactions. Prog. Food Nutr. Sci. 5:159-176.

International Dairy Federation. 1993. Milk determination of nitrogen content. FIL-IDF Standard no. 20B. IDF, Brussels, Belgium.

Kassell, B., and R. B. Chow. 1966. Modification of the basic trypsin inhibitor of bovine pancreas. The $\varepsilon$-amino groups of lysine and the amino terminal sequence. Biochemistry 5:3449-3453.

Klee, W. A., and F. M. Richards. 1957. The reaction of $O$-methylisourea with bovine pancreatic ribinuclease. J. Biol. Chem. 229:489-504.

Moughan, P. J. 2003. Amino acid availability: Aspects of chemical analysis and bioavailability methodology. Nutr. Res. Rev. 16:127-141.

Moughan, P. J., M. P. J. Gall, and S. M. Rutherfurd. 1996. Absorption of lysine and deoxyketosyllysine in an early-Maillard browned casein by the growing pig. J. Agric. Food Chem. 44:1520-1525.

Moughan, P. J., and S. M. Rutherfurd. 1996. A new method for determining digestible reactive lysine in foods. J. Agric. Food Chem. 44:2202-2209.

NRC. 1995. Nutrient requirements of the laboratory rat. Pages 1179 in Nutrient Requirements of Laboratory Animals. 4th ed. Natl. Acad. Sci., Washington, DC.

Rutherfurd, S. M., and P. J. Moughan. 1997. Application of a new method for determining digestible reactive lysine to a range of variably heated protein sources. J. Agric. Food Chem. 45:15821586.

Rutherfurd, S. M., and P. J. Moughan. 1998. The digestible amino acid composition of several milk proteins: Application of a new assay. J. Dairy Sci. 81:909-917.

Rutherfurd, S. M., and P. J. Moughan. 2005. Digestible reactive lysine in selected milk-based products. J. Dairy Sci. 88:40-48.

Rutherfurd, S. M., P. J. Moughan, and L. van Osch. 1997. Digestible reactive lysine in processed feedstuffs - Application of a new bioassay. J. Agric. Food Chem. 45:1189-1194.

Rutherfurd, S. M., N. M. Torbatinejad, and P. J. Moughan. 2006. Available (ileal digestible reactive) lysine in selected cereal-based food products. J. Agric. Food Chem. 54:9453-9457.

van Barneveld, R. J., E. S. Batterham, and B. W. Norton. 1994. The effect of heat on amino acids for pigs. 3. The availability of lysine from heat-treated field peas (Pisum sativum cultivar Dundale) determined using the slope-ratio assay. Br. J. Nutr. 72:257-275.

Yamaguchi, M., T. Nakazawa, H. Kuyama, T. Obama, E. Ando, T.-A. Okamura, N. Ueyama, and S. Norioka. 2005. High-throughput method for N-terminal sequencing of proteins by MALDI mass spectrometry. Anal. Chem. 77:645-651.

Zar, J. H. 1984. Pages 346-347 in Biostatistical Analysis. 2nd ed. Prentice-Hall, Englewood Cliffs, NJ.

Zhang, H. L., D. F. Li, S. Y. Qiao, F. L. Wang, X. J. Chen, and P. A. Thacker. 2006. The effect of dietary homoarginine derived from guanidination of synthetic lysine on endogenous amino acid loss and apparent and true ileal amino acid digestibility in the pig. Anim. Sci. 82:23-30. 